\title{
Psychological Features of Formation of Emotional-Will Sphere of Athlete Personality
}

\author{
Shohrukh Salihov, \\ Bukhara State University, Uzbekistan \\ Malika Umidjanova \\ Bukhara State University, Uzbekistan
}

\begin{abstract}
Numerous data on the personality characteristics of athletes and non-athletes show significant differences in the levels of expression of a range of personality qualities. Inspection of big groups of athletes of high qualification shows that most characteristics of their personality are: high emotional stability, self-confidence, independence, independence, tendency to risk, self-checking, sociability.
\end{abstract}

Key words: personality, athlete, emotional-will sphere, aggressiveness, motivation, mental tension, motive of achievement.

At present the issue of "personal profile" of the athlete engaged in a certain sport is quite widely discussed. However, the analysis of personal features of athletes of the international class on sports did not confirm the hypothesis of "personal profile."

More productive was the approach of finding common manifestations of personality that lead to success in sports. Among such features should be: sensivity, emotional resistance, activity in overcoming obstacles.

According to American sports psychologists, the most common personal traits of athletes include:

- High level of aggressiveness (which is almost always under control of the athlete of high class),

- High level of achievement motivation,

- Extroversion and character hardness,

- authoritativeness,

- Emotional stability and self-control [1].

Aggression. In many sports, especially those where direct physical contact is allowed, various forms of controlled physical aggression are simply necessary. Research data show that high-class athletes engaged in these sports are not only more aggressive, but also tend to express their aggressive tendencies more freely than representatives of the so-called normal sample. At the same time aggressiveness is expressed in different ways in athletes engaged in different sports.

Motivation to achieve success in athletes. Motivation is a key variable of mastering sports skills, the ability to demonstrate them. Motivation is, first of all, a desire for success, high results in its activities. And if a person, seeks to achieve success, high results in activity, 
he has quite strong motivation of achievement. The main psychological feature of the motives that encourage a person to engage in sports is the sense of satisfaction caused by the activities of this sport and inseparable from the sports activity itself.

From the analysis of literary sources devoted to this problem, it follows that a special place in psychological support of sports activity is occupied by motivation, which encourages a person to engage in sports. The motivation unit forms needs, motives and goals of sports activity.

E.P. Ilin notes that at the initial stage the reasons for entering sports (regardless of activity, i.e. sports) may be:

aspiration to self-improvement;

The desire for self-expression and self-affirmation;

social installations;

Satisfaction of spiritual and material needs [2].

Each of the listed reasons has more or less efficiency for a particular athlete due to its value orientations.

American psychologist B. J. Cretti identifies:

Seeking and overcoming stress; He notes that fighting to overcome obstacles, to expose yourself to stress, to change circumstances and to achieve success is one of the strongest motives of sports activity;

commitment to excellence;

increase in the social status;

Need to be a member of sports team, group, part of team;

receiving material encouragement.

Y.Y. Palayma allocated two groups of the athletes differing for the dominating motive. In the first group, provisionally called "collectivists," social, moral motives are dominant. In the second group - "individualists" - the leading role is played by motives of self-affirmation, self-expression of personality. The former perform better in teams, and the latter, on the contrary, - in personal competitions.

The social motive is characterized by awareness of the social significance of sporting activity; Athletes with dominance of this motive set for themselves high perspective goals, they are passionate about sports activities. The motive of self-assertion is characterized by excessive orientation of athletes on evaluation of the sports results. [5]

The results of practical studies conducted by sports psychologists show that contact with opponents or partners is also an important motivational feature of the chosen sport. Three main types of contacts are distinguished: direct (in hockey, boxing, wrestling, rugby, etc.), mediated (volleyball, football, chess, basketball, tennis, etc.) and conditional (swimming, gymnastics, etc.) [3]

Activity in sports of the highest achievements is connected with high psychological tension caused by non-compliance of requirements of sports activity to opportunities of the athlete and aimed at elimination of this non-conformity. [4] In comparison with other activities, 
in sports high mental tension is fundamentally impossible, without it is impossible to exceed previous records. Therefore athletes at the stage of higher sports skill form not only motives of achievement of success, but also motives and motives of avoidance of failure. Any situation that actualizes in the athlete the motive of success, at the same time generates fears of failure. What motive arises depends on subjective estimates of the probability of achieving the goal, which are formed under the influence of competitive and life experience. Thus, a steadily dominant type of activity motivation is formed.

\section{References}

1. Beron R., Richardson D. Agressiia [Aggression] - SPb, Piter, 2000 - 352 p.

2. Il'in E.P. Psikhologiia fizicheskogo vospitaniia: Uchebnoe posobie dlia studentov pedagogicheskikh institutov. [Psychology of Physical Education: A Textbook for Students of Pedagogical Institutes.] / E.P Il'in - M.: Prosveshchenie, 1987. - 287 p.

3. Piloian R.A. Motivatsiia sportivnoi deiatel'nosti: [Motivation of sports activity:] /Piloian R.A. - M.: FiS, $1984-108$ p.

4. Singer R.N. Mify i real'nost'v psikhologii sporta: uchebnik dlia institutov fizicheskoi kul'tury. [Myths and reality in the psychology of sports: a textbook for institutes of physical education.] / R.N. Singer per. s angliiskogo / Predislovie A.V. Rodionova-M: Fizkul'tura $i$ sport $1980 \mathrm{~s} .-152 \mathrm{p}$.

5. Stanbulova N.V. Psikhologiia sportivnoi kar'ery: uchebnik dlia institutov fizicheskoi kul'tury. [Psychology of a sports career: a textbook for institutes of physical education] / N.V. Stanbulova - M.: $2005-63$ p.

Translation of the Title, Abstract and References to the Author's Language

\section{ПСИХОЛОГИЧЕСКИЕ ОСОБЕННОСТИ ФОРМИРОВАНИЯ ЭМОЦИОНАЛЬНО-ВОЛЕВОЙ СФЕРЫ ЛИЧНОСТИ СПОРТСМЕНА Шохрух САЛИХОВ, Малика УМИДЖАНОВА Бухарский государственный университет, Узбекистан}

Многочисленные данные о личностных особенностях спортсменов и лии, не занимающихся спортом, свидетельствуют о существенных различиях в уровнях выраженности целого ряда личностных качеств. Обследование больших групп спортсменов высокой квалификации показывает, что наиболее характерными особенностями их личности являются: высокая эмоциональная устойчивость, уверенность в себе, независимость, самостоятельность, склонность к риску, самоконтроль, общительность.

Ключевые слова: личность, спортсмен, эмочионально-волевая сфера, агрессивность, мотивация, психическое напряжение, мотив достиюения. 


\section{Список литературы}

1. Бэрон Р., Ричардсон Д. Агрессия - СПб, Питер, 2000 - 352 c.

2. Ильин Е.П. Психология физического воспитания: Учебное пособие для студентов педагогических институтов./ Е.П Ильин - М.: Просвещение, 1987. -287 с.

3. Пилоян Р.А. Мотивация спортивной деятельности: /Пилоян Р.А. - М.: ФиС, 1984 $108 \mathrm{c}$.

4. Сингер Р.Н. Мифы и реальность в психологии спорта: учебник для институтов физической культуры./ Р.Н. Сингер пер. с английского / Предисловие А.В. Родионова М: Физкультура и спорт 1980 с. -152 с.

5. Станбулова Н.В. Психология спортивной карьеры: учебник для институтов физической культуры./ Н.В. Станбулова - М.: $2005-63$ с. 